\title{
On the Nature of Human Persons and the Resurrection of the Body
}

\author{
Stewart Goetz \\ Ursinus College
}

\begin{abstract}
In this paper, I respond to Joshua Mugg and James T. Turner, Jr.'s claim that the doctrine of the resurrection requires the numerical sameness of ante- and post-mortem bodies. I argue that they have not shown that Scripture teaches this view and, therefore, that animalism, as opposed to substance dualism, does not offer a superior explanation for the necessity of the resurrection.
\end{abstract}

\section{Introduction}

According to Joshua Mugg and James T. Turner, Jr., "[t]he truth of the Christian account of the afterlife implies the eschatological bodily resurrection" (Mugg and Turner 2017, 123). In addition, they believe the resurrection of the body requires the resurrection of the numerically same body that one had in this life. Because of this requirement they contend that animalism, which is generally speaking the view that we are biological organisms, has an easier time than substance dualism of explaining why God would resurrect bodies. After all, if we are animals and survive death as the numerically same individuals, then it is plausible to think that our resurrection bodies are numerically identical with our ante-mortem bodies. Mugg and Turner conclude that animalism is more likely true than dualism, because it must make fewer assumptions than dualism to explain why God would resurrect the numerically same bodies.

I agree with Mugg and Turner that the Christian account of the afterlife endorses the bodily resurrection of the dead. While I disagree with animalism, I will not say much against it here (but see Goetz 2018a). My primary concern in this brief paper is Mugg and Turner's view that the resurrection of the dead requires the resurrection of the numerically same body that a person had in this life. In what follows, I briefly summarize their argument that resurrection requires the numerical identity of the post-mortem with the ante-mortem body, and then explain why I believe they are wrong.

\section{Mugg and Turner's Case for the Numerical Sameness of the Ante- and Post-Mortem Body}

Journal of Analytic Theology, Vol. 6, December 2018

10.12978/jat.2018-6.181919061425

(C) 2018 Stewart Goetz • (C) 2018 Journal of Analytic Theology 
Mugg and Turner discuss St. Paul's treatment of the resurrection in 1 Corinthians 15 (especially verses 44-54). They maintain that, at a minimum, it is not clear that he has in mind a numerical distinction between bodies sown and bodies raised. After making some fairly technical exegetical points, they construe St. Paul's claim that "this" mortal nature or body is destined to put on immortality (verse 53) as evidence that he believed in the numerical identity of ante- and post-mortem bodies (Mugg and Turner, 126).

Mugg and Turner also devote some space to texts/issues in the Gospels that bear upon the resurrection (Mugg and Turner, 126-127). On the one hand, they point out that Jesus' post-mortem body seemingly has new properties (e.g., it can seemingly appear and disappear from spatial locations, presumably in a way that his antemortem body could not), which some people believe suggests that his post-mortem body is not numerically identical with his ante-mortem body. ${ }^{1}$ On the other hand, Jesus shows the nail prints in His hands and feet to his disciples, which might be taken to imply the numerical sameness of His post-mortem body with His ante-mortem body. But then again, on some occasions the disciples did not even recognize that they were speaking with Jesus.

In spite of the lack of clarity in these texts about the nature and identity of Jesus' resurrection body, Mugg and Turner conclude that the empty tomb of Jesus supports the numerical identity of that body with His ante-mortem body:

[T] he numerically same body that was crucified, died, and was buried is the one that, once resurrected, walked out of the tomb.... Matthew [the author of the first Gospel] is making the implied point that the resurrection explains the body's absence. The body has not been obliterated or stolen.... In sum, we agree with Stephen T. Davis ... when he asserts "I believe that this much can be affirmed and confidently taught within the Christian community: [Jesus' resurrection body] was numerically identical with his pre-resurrection body ... but not qualitatively identical with it (some of the old properties were still there, but it possessed new ones as well)." (Mugg and Turner, 127; see Davis 1993, 58)

In the context of considering the Gospel evidence, Mugg and Turner introduce a theological consideration in favor of the view that the resurrection body of Jesus was numerically the same as the dead body placed in the tomb. They point out that given that the purpose of the resurrection is to set things right, "[o]bliterating Jesus'

\footnotetext{
${ }^{1}$ An editor points out that someone who believes that the ability of Jesus' post-mortem body to suddenly appear and disappear from locations counts against it being numerically identical with his ante-mortem body assumes that Jesus's ante-mortem body could not suddenly appear and disappear from locations. I, Mugg, and Turner agree. But while Mugg and Turner doubt that Jesus' post-mortem body's being able to suddenly appear and disappear shows that His post-mortem body was not numerically identical with His ante-mortem body, they acknowledge, without explicitly questioning (Mugg and Turner, 126), that on a traditional way of reading the Gospels Luke and John, being able to suddenly appear and disappear from locations is a property not had by Jesus' ante-mortem body.
} 
dead body and replacing it with a numerically distinct new body is not putting the dead body to right; it is removing it from existence" (Mugg and Turner, 127).

Finally, Mugg and Turner point out that many respectable thinkers in the Christian tradition have affirmed the numerical identity of ante- and post-mortem bodies. They quote Aquinas (Mugg and Turner, 128), but could just as easily have cited Augustine (see Bynum 1995). And they also believe the affirmation "I believe in ... the resurrection of the body" in the Apostles' Creed (Mugg and Turner, 127) supports numerical identity.

\section{Response to Mugg and Turner: St. Paul and the Christian Tradition}

Have Mugg and Turner made their case that the resurrection of the body requires the numerical sameness of the ante- and post-mortem body? I believe they have not.

I concede Mugg and Turner's point that, at a minimum, St. Paul (in 1 Corinthians 15 , especially verse 44 ) does not explicitly make a point about the numerical distinction between bodies sown and bodies raised. In line with this concession, however, I believe it is equally clear that, at a minimum, St. Paul does not explicitly make a point about the numerical sameness between bodies sown and bodies raised. I believe the truth is that he does not explicitly address the issue of numerical sameness and difference, principally because he is concerned with the issue of kinds of bodies (here, see especially verse 35, which sets the framework for the discussion in the following verses), not the numerical identity of tokens of those kinds. Commentators recognize that verses including and subsequent to verse 35 stress kinds/types of bodies. Joseph Fitzmyer $(2008,586)$ writes that "[i]n [verses] 36-41, Paul argues analogically about 'the kind of body.'" And concerning verses 3541 , N. T. Wright $(2003,343,344)$ claims Paul insists "there are many different types of body" and that "Paul's main purpose here [verses 39-41] is to establish that there are different kinds of physicality." Wright adds about verse 44 that a soma psychikon is a body animated by the ordinary breath of life, while the soma pneumatikon is a body animated by the spirit of the living God $(2003,354)$. Again, this is a point about different kinds of bodies.

Given that in the verses just mentioned Paul is concerned about kinds of bodies, it is not in the least unnatural to understand the idea in verses 53 and 54 of "this corruptible and mortal body putting on incorruptibility and immortality" as "this corruptible and mortal kind of body being replaced by or transformed into an incorruptible and immortal kind of body." I was recently standing at the bus terminal in Oxford and overheard someone reading a bus schedule say "This London bus runs frequently." I take it the person meant something like "Busses of this kind that go to London run frequently." The individual was not referring to a particular, individual bus of that kind. Similarly, I take it that "this corruptible and mortal body" can plausibly be taken to refer to bodies of the kind that are corruptible and mortal. It need not be understood as referring to a particular, individual body of that kind. This reading is compatible with (but does not entail) the idea that the "stuff" that 
ultimately makes up a corruptible and mortal kind of body can and will somehow be transformed in a way that will allow it to compose a kind of body that is incorruptible and immortal. But such a transformation does not require that the numerically same bits and pieces of stuff that make up one person's earthly body also make up that individual's resurrection body.

What about the Christian tradition concerning the resurrection of the body? I concede that theologians like Augustine (Augustine 1993, Book 22; Bynum 1995, 94104) and Aquinas (Aquinas 1957, Chapters 80-88; Bynum 1995, 256-271) insisted on the numerical sameness of ante- and post-mortem bodies. However, I believe they were wrong in doing so because they were right about what is required for numerical sameness of bodies. They believed that the identity of a whole requires the continued presence of the parts that make it up (as Mugg and Turner point out, this is the philosophical view known as "mereological essentialism"). Given that the parts of our bodies are continually changing, not only does it seem that we have a continuous succession of numerically different bodies in this life, but also the problem arises about which of these different bodies will make up the resurrection body. Will one's resurrection body be numerically identical with that which one had as one drew one's last breath, whether that be at three months of age, three years of age, thirty years of age? Or will one's resurrection body be numerically identical with one that one had prior to the time of one's death? Augustine, Aquinas, and other theologians were well aware of the difficulties that come with providing a principled answer to these questions. Moreover, they also wrestled with the question of what would happen if one or more of the parts of the body that would make up the resurrection body were also parts of another person's body, where those parts would, according to the principle invoked, be needed to make up that person's resurrection body. Which resurrection body would have the ultimate claim to those parts? As Augustine and Aquinas knew all too well, there is no obvious answer to this conundrum.

One way to solve these problems would be to contest the mereological principle that the numerical sameness of a whole requires the numerical sameness of its parts. Mugg and Turner explicitly deny this principle (Mugg and Turner, 137). A major problem is what to put in its place. Here they are noncommittal. They deny that one's human body at death could be resurrected as a coffee mug, because there must be some kind of continuity of matter between ante- and post-mortem bodies. But how much continuity is required? Not surprisingly, the proverbial devil is in the details. Ninety-nine percent? Ninety-eight percent? Seventy percent? Fifty-one percent? There seems to be no principled answer to this question. Mugg and Turner write that " $[\mathrm{t}]$ his is not the place to give a detailed solution to the problem of persistence through change and ship-of-Theseus-type problems" (Mugg and Turner, 137). Given the number of ship-of-Theseus-type problems involved in accounting for the numerical sameness of the ante- and post-mortem body, we should at least wonder whether Paul is asserting their numerical sameness, especially in a context where he explicitly frames the overall discussion in terms of a question (1 Corinthians 15:35) about the kind of body that is involved in the resurrection.

Someone might wonder whether the ship-of-Theseus questions make any difference in one's opinion about whether Paul is asserting the numerical sameness of the ante- and post-mortem body. It is plausible to think that Mugg and Turner raise 
and discuss the ship-of Theseus questions ${ }^{2}$ because they recognize that some persons have considered these questions when pondering the identity of the resurrection body. Augustine and Aquinas affirmed the numerical identity of ante- and postmortem bodies in the face of ship-of-Theseus questions. Others (e.g., C. S. Lewis; see Goetz 2015, 138-140) denied the numerical identity of these bodies in the face of these questions.

One might hold it is a conceptual truth that resurrection implies the numerical sameness of ante- and post-mortem bodies. But Mugg and Turner seem not to hold this. They appear to distinguish between the affirmation that there is a resurrection of the dead and the claim that it is in one's ante-mortem body, which leaves open the possibility that it might not have been in one's ante-mortem body.

In a written comment, an editor of this journal asks about the distinction between resurrection and reincarnation: Might it not be the numerical sameness of ante- and post-mortem bodies that distinguishes the one from the other? The question assumes resurrection is not reincarnation. At this point, one needs to know what "reincarnation" means. If it means the re-embodiment of a soul one or more times in the future with the goal of attaining permanent disembodiment, then resurrection is not reincarnation. However, if it means something like a soul's onetime and everlasting re-embodiment in a body that is fully human in the sense that it allows for the exercising/actualization of that soul's powers/capacities which is requisite for its experiencing the perfect happiness for which it is created (I briefly discuss the issue of perfect happiness later in the paper), then resurrection is reincarnation.

\section{Response to Mugg and Turner: The Creeds and the Body of Jesus}

My understanding of the resurrection implies that there is no need for the partial or complete numerical identity of ante- and post-mortem bodies (for the sake of readability, I will largely omit "partial or complete" from here on). And I believe none of the Christian Creeds that Mugg and Turner cite requires the numerical identity of these bodies. As I have already mentioned, Mugg and Turner believe the words "I believe in ... the resurrection of the body" in the Apostles' Creed support the numerical identity of ante- and post-mortem bodies (Mugg and Turner, 127). But the Apostles' Creed does not explicitly say anything about the numerical sameness of ante- and post-mortem bodies. Mugg and Turner also appeal to Chalcedonian Christology in support of the numerical sameness of ante- and post-mortem bodies:

\footnotetext{
2 "[L]et A be the body of some individual and let B be that same body 21 years later. Suppose that all the atoms composing a person's body are replaced over the course of 21 years. Unless one affirms mereological essentialism (we do not), there is no problem in affirming $A$ is numerically identical to B.... This is not the place to give a detailed solution to the problem of persistence through change and ship-of-Theseus-type problems" (Mugg and Turner, 137).
} 
According to Chalcedon, Christ is a human being, even in his exalted state. If persons in a glorified state cannot be human, then neither can Jesus be resurrected qua human. He could only be resurrected qua person.... [A]ccording to the Definition of Chalcedon: "our Lord Jesus Christ is ... perfect in Godhead and perfect in manhood. (Mugg and Turner, 132; emphases are Mugg and Turner's).

Mugg and Turner add that they "read 'man' ... to be shorthand for 'human'” (Mugg and Turner, 132). But even if "man" means "human," Mugg and Turner have not established that Jesus, in order to be resurrected as human, must have had the numerically same body in His post-mortem existence as He had in his ante-mortem existence.

But didn't Jesus have the numerically same body before and after His entombment? Mugg and Turner claim that "Matthew is making the implied point that the resurrection explains the body's absence" (Mugg and Turner, 127), and it is most plausible to think that it could explain this only if "the numerically same body that was crucified, died, and was buried is the one that, once resurrected, walked out of the tomb" (Mugg and Turner, 127).

In response, I turn to some comments by the mid-twentieth-century British Christian, novelist, and playwright Dorothy L. Sayers. In her notes to her play The Man Born to Be King, she writes that "[i]t seems clear that the rolling back of the stone by the Angel was not done to let the Body out. A form that could pass through barred doors or vanish into thin air from the supper-table was not going to be baulked by a few hundred-weight stone" (Sayers 1990, 311). Thus, contrary to what Mugg and Turner's statement about Matthew's implied point suggests, there is no need to insist that Jesus had to or did walk out of the tomb. But why, then, was the stone rolled back? Sayers writes that " $[t]$ he door was opened in order to draw the attention of the guards and the disciples to the fact that the Body was gone.... [W] can presume that when the Angel rolled back the stone, it was to disclose the tomb already empty" (Sayers 1990, 311). Sayers then adds the following:

There is no reason to imagine that the Body [of Jesus] was obliged always to carry Its original physical components about with It. Presumably It could build Itself up from any atomic material that happened to be handy. But the disappearance of the original earthly body was obviously necessary as evidence [that Jesus was alive]. (Sayers 1990, 312)

Sayers's overall conclusion is that "it is unnecessary, either for faith or morals, to have any fixed views on the physical mechanism of the Resurrection" (Sayers 1990, 311). "The Church," she writes elsewhere, "binds us to no theory about the exact composition of Christ's Resurrection Body" (Sayers 2004, 5). Like her, I believe it is plausible to think that the earthly body of Jesus that was placed in the tomb had to disappear from the tomb in order to convince the followers of Jesus (and others) that He had been resurrected. This is an epistemological issue. As Sayers wrote, the disappearance of the body was evidence of Jesus' resurrection. But while some, most, 
or even all of the components of Jesus's ante-mortem body might have been present in His resurrection body (Sayers does not deny this was the case), there is also no reason to hold that Jesus' having a resurrection body, which is a metaphysical issue, required (Sayers writes "obliged") the partial or complete numerical identity of that body with His ante-mortem body (which had disappeared).

But doesn't a natural reading of the relevant Gospel texts suggest that at least some of the components of Jesus' ante-mortem body were present in his resurrection body? I think a natural reading of some texts (e.g., those about the empty tomb) suggests this, while a natural reading of others leaves one wondering. If Jesus' postmortem, but not His ante-mortem, body could pass through walls and vanish into thin air (e.g., John 20: 26; Luke 24: 36; 24:31), then it is hard to avoid puzzling over the question whether His post-mortem body was an instance of a different ontological kind of body with numerically different components than those present in His antemortem body.

I think it is reasonable to conclude that the nature and identity of Jesus' resurrection body is shrouded in mystery. The disciples certainly did not know what to make of the resurrection of their Lord. Though Jesus shows Thomas and the others the holes in His hands, side, and feet, thus convincing them that it was He who was with them, at other times they did not even recognize Him. It is all so impenetrable. Hence, the claim that the data in the Gospels unequivocally support the numerical sameness of the ante- and post-mortem bodies of Jesus just isn't credible.

\section{Setting Things Right and Substance Dualism}

Given the impenetrability of the nature and identity of Jesus' resurrection body, perhaps it is wise to step back and remember that the resurrection of the body is not an end in itself. In other words, perhaps it is wise to remember that God's ultimate purpose in creating human beings is not that they have resurrection bodies. At best, having a resurrection body is a means to the ultimate end for which God did create human beings. In accordance with the vast weight of Christian tradition, I believe God's ultimate purpose in creating us was that we experience perfect happiness (i.e., enjoy God forever, experience complete felicity or beatitude). And the fact that this was God's purpose in creating us casts light on Mugg and Turner's claim that "the purpose of the resurrection is to set things right" (Mugg and Turner, 126). What ultimately needs to be set right is that we experience the perfect happiness for which we were created (provided we die to self, repent of our sinful way of life, etc.). The question is can this setting right of things be accomplished without our having the numerically same bodies post-mortem that we had ante-mortem. What I have a hard time seeing is how our retaining our present bodies is in any sense required for our experiencing perfect happiness in the afterlife; how retaining our current bodies is in some sense necessary for finally setting things right in terms of that happiness. 
Perhaps our retaining the numerically same bodies in some different state is compatible with setting things right. But I fail to see how it is necessary. ${ }^{3}$

Mugg and Turner, might respond at this point that it is we who will experience perfect happiness, and because we are biological organisms, our bodies must, with their numerical sameness, continue on into the resurrection life. After all, they believe in animalism. It is here that I think we see just how at odds animalism is with the vast weight of Christian tradition. As Mugg and Turner write, "the Christian tradition has-almost universally-agreed that some form of substance dualism is the case" (Mugg and Turner, 139). But why has the Christian tradition almost universally come down on the side of substance dualism (dualism, for short)?

For starters, there is evidence which suggests that it seems to most people that they are not their bodies. As I have pointed out elsewhere (see Goetz 2012a and 2016), even naturalistic non-dualists admit this. For example, Charles Darwin was convinced that most people affirm dualism. He wrote the following at the end of his The Descent of Man:

If ... we include under the term "religion" the belief in unseen or spiritual agencies ... this belief seems to be universal with the less civilized races.... As Mr. M'Lennan has remarked, "Some explanation of the phenomena of life, a man must feign for himself; and to judge from the universality of it, the simplest hypothesis and the first to occur to me, seems to have been that natural phenomena are ascribable to the presence in animals, plants, and things, and in the forces of nature, of such spirits prompting to action as men are conscious they themselves possess." (Darwin 1989, Part One, 98)

The belief in God has often been advanced as not only the greatest, but the most complete of all the distinctions between man and the lower animals. It is however impossible ... to maintain that this belief is innate or instinctive in man. On the other hand a belief in all-pervading spiritual agencies seems to be universal; and apparently follows from a considerable advance in man's reason, and from a still greater advance in his faculties of imagination, curiosity and wonder. I am aware that the assumed instinctive belief in God has been used by many persons as an argument for His existence. But this is a rash argument, as we should thus be compelled to believe in the existence of many cruel and malignant spirits, only a little more powerful than man; for the belief in

\footnotetext{
${ }^{3}$ A referee asks about cases of injustice in this life in which one suffers because of the specific body that one has (e.g., cases of racism or sexism). Does addressing injustice require that one have the numerically same body in the resurrection life?

If the referee is suggesting that one who suffers injustice in this life because of one's race or sex must have the numerically same body with its race and sex in the resurrection, then what about one who is treated unjustly for being (congenitally?) lame or blind? Does addressing these injustices require that one have the numerically same lame or blind body in the resurrection life? Because it is not clear to me what principle of justice the referee is invoking in the objection, I believe it is wisest to say nothing further here about the issue.
} 
them is far more general than in a beneficent Deity. (Darwin 1989, Part Two, 637)

More recently, the experimental cognitive scientist Jesse Bering writes that human beings are believers in dualism (Bering 2006), and the psychologist Nicholas Humphrey insists that there is a human inclination to believe in dualism. Toward the end of his book Soul Dust, Humphrey mentions other scholars who also acknowledge this ordinary belief in dualism:

Thus, development psychologist Paul Bloom aptly describes human beings as "natural-born dualists." Anthropologist Alfred Gell writes: "It seems that ordinary human beings are 'natural dualists,' inclined more or less from day one, to believe in some kind of 'ghost in the machine' ...." Neuropsychologist Paul Broks writes: "The separateness of body and mind is a primordial intuition... Human beings are natural born soul makers, adept at extracting unobservable minds from the behaviour of observable bodies, including their own." (Humphrey 2011, 195)

Thus, while Bering, Humphrey, Bloom, Gell, and Broks no longer affirm the truth of dualism (for reasons I need not go into here), they nevertheless acknowledge (like Darwin) that human beings naturally believe it. So animalism cuts deeply against the grain of the widespread belief in dualism. ${ }^{4}$ But further, if we are ultimately created by God for perfect happiness and that happiness will be in part, if not in whole, constituted by experiences of pleasure (and the absence of experiences of pain), 5 then we should remember that the problem of qualia has proven to be one of the chief buga-boos of physicalism. To this day, there is no plausible account of how an experience of pleasure, which seems to be something with no internal part-whole structure, can be identical with a complex bodily event (of course, one can just assert their identity and have it over with). ${ }^{6}$ And if perfect happiness consists at least in part of

\footnotetext{
${ }^{4}$ The editor who raised the distinction between resurrection and reincarnation which I mentioned earlier in the body of this paper states that he/she does not think the quotations I provide in support of the apparent universal belief in dualism are sufficient to establish the reality of this universal belief. Maybe they are not sufficient (what would be sufficient in this case?), but they certainly are relevant.

Perhaps even more relevant at this point is the editor's own reference to the distinction between resurrection and reincarnation. As J. P. Moreland has reminded me, reincarnation is widely accepted in Eastern religions (e.g., Hinduism) and presupposes the existence of a soul that is distinct from any material body that it might have (even classical Buddhism, which ultimately denies the existence of a substantial soul, concedes we initially believe in its existence). Thus, belief in reincarnation itself supports the universal nature of the belief in dualism.

${ }^{5}$ I have defended the hedonic character of perfect happiness in Goetz 2012b, and explained C. S. Lewis's hedonic understanding of perfect happiness in Goetz 2015 and 2018b.

${ }^{6} \mathrm{~A}$ referee informs me that Turner (the reviewer is unsure about Mugg) is a hylomorphic animalist who believes that a human person is identical with his or her human animal body, where the human animal body is composed of physical material informed by an immaterial form. Hence, the referee suggests my point about the difficulty of incorporating qualia into a physicalist understanding of persons misses the mark against Turner because Turner is not a physicalist.
} 
experiences of pleasure that are not identical with physical events of any kind, then it is hard to see why the numerical sameness of our ante- and post-mortem bodies is required for our experience of perfect happiness (though there is also no reason to think that dualism as such is incompatible with the numerical identity of antemortem and post-mortem bodies and the perfect happiness experienced with the latter). Indeed, it is hard to see why, in the words of Mugg and Turner, "bodily resurrection is essential for eschatological afterlife" (Mugg and Turner, 123; emphasis is Mugg and Turner's). At this point, I agree with others (Mugg and Turner quote Plantinga) who believe our afterlife includes embodiment because embodiment will promote our perfect happiness (flourishing). But I believe the resurrection will promote our experience of perfect happiness only because God has chosen to make bodily pleasures (pleasures whose source is bodily in nature) part of that experience. ${ }^{7}$ The experience of such pleasures is ultimately a gift and something for which to be eternally grateful. In no way, however, does the truth that we are created for perfect happiness, one of whose sources is bodily in nature, imply the truth of animalism.

But why, one might wonder, if dualism is true, could not God give us bodily pleasures directly, without our having bodies? If God could do this, then it seems that the experience of bodily pleasure does not require embodiment and so bodily resurrection is superfluous. Moreover, it is not clear how my point about perfect happiness shows that embodiment, qua embodiment, is good.

Three brief points are relevant in response. First, if God sustained bodiless subjects in existence in the afterlife and caused or allowed them to believe, as a matter of course, that they had bodies and that certain of their experiences of pleasure were bodily in nature (had their bodies as ultimate sources), then it would be hard to avoid the conclusion that God was a systemic deceiver. ${ }^{8}$ What reason would God have for

One might simply respond that if Turner is not a physicalist, then he is not an animalist. But let's assume one can hold that the material human animal body is informed by an immaterial form and still be an animalist. We now certainly seem to be on the border of, if not in, dualist territory.

If the immaterial form is substantial in nature and capable of existing after death apart from its material human corpse (it can survive death either embodied or disembodied), then it seems the requisite numerical sameness for ante- and post-mortem existence of the person/self resides in the immaterial substantial form; it is the numerical sameness of the immaterial substantial form that is doing the real work in terms of preserving numerical identity of the self and serving as the subject of qualia (and propositional attitudes), not the animal body. With respect to the overall point of Mugg and Turner's paper, one might also ask how this seemingly dualist version of animalism has an easier time than substance dualism of explaining why God would resurrect bodies?

If the immaterial form is not substantial and cannot exist apart from the material, then it remains open to question (as the referee acknowledges) whether this understanding of a form is adequate for avoiding physicalism. If it is maintained this version of animalism avoids physicalism because the form is an immaterial property or aspect of the human animal body, then once again we are near, if not in, dualist territory, and my point that it is hard to incorporate qualia into a thoroughly physicalist understanding of the self/person seems apropos.

${ }^{7}$ For a brief survey of less hedonistic explanations for bodily resurrection, see Rickabaugh 2018.

${ }^{8}$ And if God could, as a matter of course, make it seem to bodiless subjects that they experienced bodily pleasures in an apparent body (experiencing bodily pleasures comes with the appearance of having a body), while at the same time making it clear to them that they did not have bodies, these subjects would naturally wonder what reason God had for setting things up this way. Without a reasonable explanation, this situation would seem to provide little, if any, improvement in terms of things making 
needing to engage in such deception? Second, I am not claiming that embodiment per se (embodiment as such) is good. I am maintaining that embodiment is instrumentally good as a source of pleasure, where the pleasure is intrinsically good. Third, the most basic question is "What kind of entity experiences pleasure?" This question is not answered by pointing out the different souces (e.g., bodily and mental) of pleasure. That $\mathrm{X}$ is a source of pleasure for $\mathrm{S}$ does not entail or provide evidence for the view that $\mathrm{S}$ is $\mathrm{X}$.

\section{Conclusion}

I conclude that Mugg and Turner have failed to show that animalism is more likely true than dualism because they have failed to show that resurrection requires the numerical sameness of ante- and post-mortem bodies. And they have failed to show this because they have failed to show, contrary to what they claim (Mugg and Turner, 130), that Scripture teaches numerical sameness of ante- and post-mortem bodies.

At this point, I believe it is important to make clear that I do not disagree with Mugg and Turner's position because I maintain Scripture teaches the numerical difference of ante- and post-mortem bodies. I do not think this is the case. Rather, I believe Scripture does not teach anything about the topic of the numerical identity of ante- and post-mortem bodies, because I believe it was not written to teach anything about it. The view that it was is, I am convinced, mistaken.

What about the topic of animalism versus dualism? While I believe dualism is true, I believe Scripture was not written to teach dualism (see Cooper 1989), because I believe it was not written to teach us the metaphysics of the nature of the self, period. Rather, I believe Scripture just takes for granted what we ordinarily believe about ourselves, which is, as Darwin and scholars like Bering, Humphrey, and others confirm, dualism. But though I believe Scripture does not teach dualism, I also believe dualism is readily expressed in the statements of Jesus, St. Paul, and ordinary people in Scripture. ${ }^{9}$ Indeed, if animalism (or some other non-dualist view) were expressed in those statements, it would lead me to question the truth of Scripture. But I will say nothing more about this matter here. ${ }^{10}$

sense over the situation in which God causes bodiless subjects to believe they had bodies without informing them that their belief was false.

${ }^{9}$ I have addressed this issue in Goetz 2012a and Goetz 2016. See also Cooper 1989.

10 I thank Craig Blomberg, Jonathan Loose, Timothy Mawson, J. P. Moreland, Charles Taliaferro, two anonymous referees, and an editor of this journal for many helpful discussions about, comments on, and corrections of this paper. 


\section{Bibliography}

Aquinas, Thomas. 1957. On the Truth of the Catholic Faith: Summa Contra Gentiles; Book Four: Salvation, translated by Charles J. O'Neill. Garden City, NY: Image Books.

Augustine. 1993. The City of God. Translated by Marcus Dods. New York: The Modern Library.

Bering, Jesse. 2006. "The Folk Psychology of Souls." Behavioral and Brain Sciences 29: 453-462.

Bynum, Caroline Walker. 1995. The Resurrection of the Body in Western Christianity, 200-1336. New York: Columbia University Press.

Cooper, John. 1989. Body, Soul, and Life Everlasting: Biblical Anthropology and the Monism-Dualism Debate. Grand Rapids, MI: Eerdmans.

Darwin, Charles. 1989. The Descent of Man, and Selection in Relation to Sex. Vols. 2122 in The Works of Charles Darwin, edited by Paul H. Barrett and R. B. Freeman. New York: New York University Press.

Davis, Stephen T. 1993. Risen Indeed: Making Sense of the Resurrection. Grand Rapids, MI: Eerdmans.

Fitzmyer, Joseph A. 2008. First Corinthians. New Haven: Yale University Press.

Goetz, Stewart. 2012a. "Is N. T. Wright Right about Substance Dualism?" Philosophia Christi 14: 183-91.

. 2012b. The Purpose of Life: A Theistic Perspective. New York: Continuum.

.2015. A Philosophical Walking Tour with C. S. Lewis: Why It Did Not Include

Rome. New York: Bloomsbury.

. 2016. "Substance Dualism." In The Ashgate Research Companion to Theological Anthropology, edited by Joshua R. Farris and Charles Taliaferro, 125-37. New York: Routledge.

. 2018a. "Against Animalism." In The Blackwell Companion to Substance Dualism, edited by Jonathan J. Loose, Angus J.L. Menuge, and J.P. Moreland, 307-15. Oxford, UK: Wiley Blackwell.

. 2018b. C. S. Lewis. Oxford, UK: Wiley-Blackwell.

Humphrey, Nicholas. 2011. Soul Dust. Princeton University Press. 
Mugg, Joshua and James T. Turner, Jr. 2017. “Why a Bodily Resurrection?: The Bodily Resurrection and the Mind/Body Relation." The Journal of Analytic Theology 5: 121-144.

Rickabaugh, Brandon. 2018. "Dismantling Bodily Resurrection Objections to MindBody Dualism." In Christian Physicalism? Philosophical Theological Criticisms, edited by R. Keith Loftin and Joshua R. Farris, 295-317. New York: Lexington Books.

Sayers, Dorothy L. 1990. The Man Born to Be King. Ignatius Press.

2004. Letters to a Diminished Church: Passionate Arguments for the Relevance of Christian Doctrine. Nashville, TN: Thomas Nelson.

Wright, N. T. 2003. The Resurrection of the Son of God. London: SPCK. 